\title{
Expression of blood group antigens in urinary tract tumours: prospective fluorescence study using cryostat sections of fresh frozen tissues
}

\author{
SUSAN J THORPE,* P ABEL, $†$ D HENDERSON, $\dagger$ NICOLA JONES,* TEN FEIZI \\ From the *Applied Immunochemistry Research Group, Medical Research Council Clinical Research Centre, \\ Harrow, Middlesex and the Departments of †Urology and Histopathology, Freeman Hospital, Newcastle upon \\ Tyne
}

SUMMARY Cryostat sections of fresh frozen tissues were used in a prospective study of blood group $\mathrm{H}$ and $\mathrm{A}$ antigen fluorescence in 73 transitional cell carcinomas of the bladder. The aim was to evaluate antigen expression without subjecting the tumour tissues to organic solvents that extract blood group active glycolipids. Deletion of the genetically predicted antigen was twice as common in tumours of pT1 or greater stage than those of pTa stage and also twice as common in poorly differentiated than in moderately well differentiated tumours. The considerable heterogeneity and overlap, however, in patterns of reactivity in tumours of various histopathological stages and grades and the effect of secretor status on antigenicity meant that there was no obvious antigenic feature that correlated precisely with invasive stage or differentiation grade.

It remains to be determined whether the antigen positive and antigen negative tumours represent different disease entities with differing clinical courses. Our results indicate, however, that studies of the blood group antigens in urinary tract tumours are more likely to be of value in research into biochemical disorders in the neoplastic process than in routine clinical assessment as a guide to treatment.

Tumours of the transitional epithelium of the bladder often recur, and up to $30 \%$ of superficial tumours eventually become invasive. ${ }^{12}$ It is highly desirable at the time of diagnosis to distinguish the superficial tumours that will have a relatively benign course and require simple endoscopic follow up from those that will eventually invade and metastasise and may require more aggressive treatment. There are at present no reliable criteria for such a distinction. Thus molecular markers have been sought in the hope that they would accurately predict bladder tumour behaviour and permit new strategies of management. Many studies have concentrated on the blood group A, B, and $\mathrm{H}$ antigens, which are normally expressed on epithelial tissues, but which may be absent or reduced in several types of epithelial carcinomas. ${ }^{3}$ Several retrospective studies using paraffin embedded bladder tumours have suggested that loss or reduction of the predicted antigen(s), as judged by the red cell adherance test, is associated with, and even precedes, invasive or metastatic recurrence. ${ }^{4-6}$ Other investigators using different methods have found no

Accepted for publication 27 May 1986 clear correlation between antigen expression and degree of malignant potential. ${ }^{7-9}$

Using indirect immunofluorescence microscopy to compare the expression of the blood group antigens in paraffin embedded and cryostat sections of bladder mucosae of patients without bladder cancer, we showed that reliable assessment of these antigens can only be made using cryostat sections of fresh frozen tissues ${ }^{10}$ as the organic solvents used to dehydrate the tissues before paraffin embedding extract, to varying degrees, the blood group antigen carrying glycolipids. ${ }^{1112}$ In this investigation we therefore used cryostat sections of bladder and ureteric tumours of various stages and grades to study the expression of the blood group $\mathrm{H}$ and $\mathrm{A}$ antigens recognised by Ulex europaeus lectin and a rabbit polyclonal anti-A serum, respectively.

\section{Material and methods}

\section{TISSUES}

Tissue samples were obtained from 76 patients with bladder tumours ( 73 with transitional cell carcinoma, two with squamous cell carcinoma, and one with ade- 
nocarcinoma) and six patients with upper urothelial tract tumours of transitional cell type, undergoing either diagnostic or follow up cystoscopy, cystectomy, or nephroureterectomy. Transurethral biopsy specimens were taken with an Olympus resectoscope and, in some cases, included adjacent non-malignant epithelium. Histological stage ${ }^{13}$ and grade $^{14}$ were determined by one of us (DH) using formalin fixed paraffin embedded sections stained with haematoxylin and eosin. These assessments were made without knowledge of the blood group antigen state of the tumours. Muscle was present in all biopsy specimens with the exception of four cases (which were clinically superficial on bimanual examination) (tables 1 and 2). For immunofluorescence, samples were immediately snap frozen in isopentane cooled with liquid nitrogen and stored at $-70^{\circ} \mathrm{C}$ before sec- tioning: cryostat sections stained with haematoxylin and eosin were examined to ensure that they were representative of the tumours. The secretor status of the patients was determined by examination of saliva, as described previously. ${ }^{15}$

\section{FLUORESCENCE MICROSCOPY}

Immunofluorescence staining was carried out as described previously. ${ }^{10}$ Briefly, cryostat sections $(6 \mu \mathrm{m})$ were air dried, fixed in acetone for 15 minutes at $4^{\circ} \mathrm{C}$, and incubated at room temperature with fluorescein conjugated Ulex europaeus (anti-H) lectin (agglutinin 1, Vector Laboratories Inc, Burlingham, California 94010, United States, purchased from BDH Chemicals Ltd, Dagenham, Essex) at 1/80 dilution, or at $4^{\circ} \mathrm{C}$ with rabbit antisera to blood group $\mathrm{H}$ or A antigens ${ }^{1016}$ (kindly provided by Dr Winifred

Table 1 Age, sex, secretor status (where known), histology of tumours and $H$ antigen fluorescence of tumours and non-neoplastic mucosae (where available) of patients of blood group $O$

\begin{tabular}{|c|c|c|c|c|c|c|c|c|}
\hline \multirow[b]{2}{*}{$\begin{array}{l}\text { Case } \\
\text { No }\end{array}$} & \multirow[b]{2}{*}{ Sex } & \multirow[b]{2}{*}{ Age } & \multirow[b]{2}{*}{$\begin{array}{l}\text { Secretor } \\
\text { status }\end{array}$} & \multicolumn{3}{|c|}{ Histology of tumour } & \multicolumn{2}{|l|}{ Fluorescence $\ddagger$} \\
\hline & & & & Stage & Grade* & Multiplicity $\dagger$ & $\begin{array}{l}\text { Morphologically } \\
\text { Tumour }\end{array}$ & normal urothelium \\
\hline $\begin{aligned} & 1 \text { (Smi) } \\
& 2 \text { (Wil) } \\
& 3 \text { (Pri) } \\
& 4 \text { (Ven) } \\
& 5 \text { (Rob) } \\
& 6 \text { (Sho) } \\
& 7 \text { (Wes) } \\
& 8 \text { (Bel) } \\
& 9 \text { (Hal) } \\
& 10 \text { (Wat) } \\
& 11 \text { (Din) } \\
& 12 \text { (War) } \\
& 13 \text { (Whi) } \\
& 14 \text { (Fin) } \\
& 15 \text { (Ken) }\end{aligned}$ & $\begin{array}{l}\text { M } \\
\text { F } \\
\text { M } \\
\text { F } \\
\text { M } \\
\text { F } \\
\text { M } \\
\text { M } \\
\text { M } \\
\text { M } \\
\text { M } \\
\text { M } \\
\text { M } \\
\text { M } \\
\text { M }\end{array}$ & $\begin{array}{l}76 \\
51 \\
62 \\
65 \\
67 \\
57 \\
79 \\
65 \\
61 \\
69 \\
70 \\
74 \\
80 \\
52 \\
77\end{array}$ & $\begin{array}{l}\text { Not determined } \\
\text { Not determined } \\
\text { Not determined } \\
\text { Secretor } \\
\text { Secretor } \\
\text { Not determined } \\
\text { Not determined } \\
\text { Not determined } \\
\text { Non-secretor } \\
\text { Secretor } \\
\text { Not determined } \\
\text { Not determined } \\
\text { Secretor } \\
\text { Secretor } \\
\text { Not determined }\end{array}$ & $\mathrm{pTa}$ & $\begin{array}{l}\mathbf{M} \\
\mathbf{M} \\
\mathbf{M} \\
\mathbf{M} \\
\mathbf{M} \\
\mathbf{M} \\
\mathbf{M}^{*} \\
\mathbf{M} \\
\mathbf{M} \\
\mathbf{M} \\
\mathbf{M} \\
\mathbf{M} \\
\mathbf{M} \\
\mathbf{W} \\
\mathbf{M}\end{array}$ & $\begin{array}{l}M \\
S \\
S \\
M \\
S \\
M \\
S \\
S \\
S \\
S \\
S \\
M \\
S^{\text {r. tu. at }} \\
M \\
S\end{array}$ & $\begin{array}{l}(1)-4^{b} \\
0-4^{b} \\
0-4^{b} \\
0-4^{b} \\
0-3^{b} \\
0-3^{b} \\
0-3^{b} \\
0-2^{b} \\
0-2^{b} \\
0-2^{b} \\
0-(2) \\
0 \\
0 \\
0 \\
0\end{array}$ & $\begin{array}{l}3-4 \\
0-4 \\
3 \\
1-2\end{array}$ \\
\hline $\begin{array}{l}16 \text { (Nur) } \\
17 \text { (Che) } \\
18 \text { (Pat) } \\
19 \text { (Kem) } \\
20 \text { (Qui) } \\
21 \text { (Robs) }\end{array}$ & $\begin{array}{l}\mathbf{M} \\
\mathbf{M} \\
\mathbf{F} \\
\mathbf{M} \\
\mathbf{F} \\
\mathbf{M}\end{array}$ & $\begin{array}{l}89 \\
52 \\
74 \\
86 \\
79 \\
75\end{array}$ & $\begin{array}{l}\text { Secretor } \\
\text { Secretor } \\
\text { Secretor } \\
\text { Secretor } \\
\text { Secretor } \\
\text { Secretor }\end{array}$ & pT1 & $\begin{array}{l}\mathbf{M} \\
\mathbf{M} \\
\mathbf{M} \\
\mathbf{M} \\
\mathbf{M} \\
\mathbf{M}\end{array}$ & $\begin{array}{l}\mathbf{S} \\
\mathbf{M} \\
\mathbf{M} \\
\mathbf{S} \\
\mathbf{S} \\
\mathbf{M}\end{array}$ & $\begin{array}{l}2-3 \\
0-4^{\mathrm{b}} \\
0-4^{\mathrm{b}} \\
0-2^{\mathrm{b}} \\
0 \\
0\end{array}$ & $3^{1-2}$ \\
\hline $\begin{array}{l}22 \text { (Mor) } \\
23 \text { (Bra) } \\
24 \text { (See) } \\
25 \text { (Gre) } \\
26 \text { (For) } \\
27 \text { (Man) } \\
28 \text { (Hep) } \\
29 \text { (Hol) } \\
30 \text { (Par) } \\
31 \text { (Fre) } \\
32 \text { (McG) } \\
33 \text { (You) }\end{array}$ & $\begin{array}{l}\mathbf{M} \\
\mathbf{M} \\
\mathbf{M} \\
\mathbf{M} \\
\mathbf{F} \\
\mathbf{M} \\
\mathbf{M} \\
\mathbf{M} \\
\mathbf{M} \\
\mathbf{M} \\
\mathbf{M} \\
\mathbf{M}\end{array}$ & $\begin{array}{l}70 \\
66 \\
79 \\
64 \\
63 \\
59 \\
78 \\
71 \\
50 \\
82 \\
70 \\
59\end{array}$ & $\begin{array}{l}\text { Not determined } \\
\text { Not determined } \\
\text { Secretor } \\
\text { Secretor } \\
\text { Secretor } \\
\text { Secretor } \\
\text { Not determined } \\
\text { Secretor } \\
\text { Secretor } \\
\text { Secretor } \\
\text { Non-secretor } \\
\text { Secretor }\end{array}$ & $\mathrm{pT} 2$ or $>$ & $\begin{array}{l}\mathbf{M} \\
\mathbf{P} \\
\mathbf{P} \\
\mathbf{M} \\
\mathbf{P} \\
\mathbf{P} \\
\mathbf{M} \\
\mathbf{P} \\
\mathbf{P} \\
\mathbf{P} \\
\mathbf{M} \\
\mathbf{P}\end{array}$ & $\begin{array}{l}\text { S. tu } \\
\mathbf{S} \\
\mathbf{S} \\
\mathbf{S} \\
\mathbf{S} \\
\mathbf{S} \\
\mathbf{M} \\
\mathbf{S} \\
\mathbf{S} \\
\mathbf{M} \\
\mathbf{S} \\
\mathbf{S}\end{array}$ & $\begin{array}{l}2 \\
1-4 \\
1-4 \\
1-3 \\
(0)-3 \\
0-3^{b} \\
0-(2)^{b} \\
0-(1) \\
0 \\
0 \\
0 \\
0\end{array}$ & $0-1$ \\
\hline
\end{tabular}

*W, $\mathrm{M}$, and $\mathrm{P}=$ well, moderately, and poorly differentiated tumours, respectively; asterisk indicates absence of muscle in biopsy specimens used for histological assessment.

tS = single tumour present; $M$ = multiple tumours present; in the invasive tumours, all of which were solitary, $M$ indicates the additional tS presence of multiple superficial tumours. The latter were not studied. Supctscript at first presentation; superscripts tu and ct indicate previous treatment by transurethral resection and intravesical chemotherapy, respectively.

+ Fluorescence intensity was graded $0-4$ and parentheses are used for areas corresponding to less than about $5 \%$, as described in the materia and methods section; superscript $b$ indicates fluorescence predominantly in tumour cells surrounding blood vessels and connective tissue. 
Table 2 Age, sex, secretor status (where known), histology of tumours and $A$ and $H$ antigen fluorescence of tumours and non-neoplastic mucosae (where available), of patients of blood groups $A$ and $A B$

\begin{tabular}{|c|c|c|c|c|c|c|c|c|c|c|}
\hline \multirow{3}{*}{$\begin{array}{l}\text { Case } \\
\text { No }\end{array}$} & \multirow[b]{3}{*}{ Sex } & \multirow[b]{3}{*}{ Age } & \multirow{3}{*}{$\begin{array}{l}\text { Secretor } \\
\text { status }\end{array}$} & \multirow{2}{*}{\multicolumn{3}{|c|}{ Histology of tumour }} & \multicolumn{4}{|c|}{ Fluorescence $₫ \S \|$} \\
\hline & & & & & & & \multicolumn{2}{|c|}{ Tumour } & \multicolumn{2}{|c|}{$\begin{array}{l}\text { Morphologically } \\
\text { normal urothelium }\end{array}$} \\
\hline & & & & Stage & Grade* & Multiplicity $\dagger$ & $A$ & $H$ & $A$ & $H$ \\
\hline $\begin{array}{l}34 \text { (Allab) }^{\text {ab }} \\
35 \text { (Harv) } \\
36 \text { (Mar) } \\
37 \text { (WilJ) } \\
38 \text { (McK) } \\
39 \text { (Jac) } \\
40 \text { (Ste) } \\
41 \text { (Bow) } \\
\left.42 \text { (Hut }{ }^{\mathrm{ab}}\right) \\
43 \text { (Ash) } \\
44 \text { (Ril) } \\
45 \text { (Oni) } \\
46 \text { (Hay) } \\
47 \text { (Ave) } \\
48 \text { (Coa) } \\
49 \text { (WilM) } \\
50 \text { (Art) } \\
51 \text { (Mar) } \\
52 \text { (Wal) }\end{array}$ & 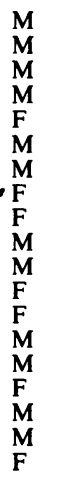 & $\begin{array}{l}74 \\
83 \\
35 \\
49 \\
66 \\
74 \\
71 \\
86 \\
59 \\
75 \\
60 \\
78 \\
79 \\
75 \\
77 \\
64 \\
96 \\
72 \\
70\end{array}$ & $\begin{array}{l}\text { Secretor } \\
\text { Secretor } \\
\text { Secretor } \\
\text { Secretor } \\
\text { Secretor } \\
\text { Secretor } \\
\text { Secretor } \\
\text { Secretor } \\
\text { Not determined } \\
\text { Secretor } \\
\text { Secretor } \\
\text { Not determined } \\
\text { Secretor } \\
\text { Not determined } \\
\text { Not determined } \\
\text { Not determined } \\
\text { Non-secretor } \\
\text { Secretor } \\
\text { Non-secretor }\end{array}$ & $\mathrm{pTa}$ & 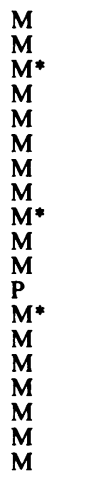 & $\begin{array}{l}S \\
S \\
S \\
S \\
S \\
S \\
M \\
S \\
S \\
S \\
S \\
S \\
M \\
S \\
M \\
S \\
S \\
S \\
M\end{array}$ & $\begin{array}{l}4 \\
3-4 \\
2-4 \\
2-4 \\
1-4^{b} \\
1-4^{b} \\
1-3^{b} \\
1-3^{b} \\
2-(4)^{b} \\
\left(0-3^{b}\right. \\
0-4^{b} \\
0-4^{b} \\
0-4^{b} \\
0-4 \\
0-2^{b} \\
0-(2)^{b} \\
0 \\
0 \\
0\end{array}$ & $\begin{array}{l}0 \\
0 \\
0 \\
0 \\
0 \\
0 \\
0 \\
0-2^{b} \\
0 \\
0-(3)^{b} \\
0-(1)^{b} \\
0 \\
0 \\
0-3 \\
0-3^{b} \\
0 \\
0 \\
0-2^{b} \\
0\end{array}$ & $\begin{array}{l}4 \\
3 \\
2-4\end{array}$ & $\begin{array}{l}0 \\
2 \\
0\end{array}$ \\
\hline $\begin{array}{l}53 \text { (KenJ) } \\
54 \text { (YouG) } \\
55 \text { (ForT) } \\
56 \text { (Oli) } \\
57 \text { (Coop) } \\
58 \text { (Bon) } \\
59 \text { (Cro) } \\
60 \text { (Fal) } \\
61 \text { (Inw) } \\
62 \text { (Liv) } \\
63 \text { (Rea) } \\
64 \text { (Sha) } \\
65 \text { (Lee) }\end{array}$ & $\begin{array}{l}\mathbf{M} \\
\mathbf{M} \\
\mathbf{M} \\
\mathbf{M} \\
\mathbf{M} \\
\mathbf{M} \\
\mathbf{F} \\
\mathbf{M} \\
\mathbf{M} \\
\mathbf{M} \\
\mathbf{M} \\
\mathbf{M} \\
\mathbf{M}\end{array}$ & $\begin{array}{l}52 \\
56 \\
67 \\
82 \\
38 \\
77 \\
65 \\
70 \\
73 \\
66 \\
60 \\
73 \\
77\end{array}$ & $\begin{array}{l}\text { Non-secretor } \\
\text { Secretor } \\
\text { Secretor } \\
\text { Secretor } \\
\text { Not determined } \\
\text { Not determined } \\
\text { Secretor } \\
\text { Non-secretor } \\
\text { Secretor } \\
\text { Non-secretor } \\
\text { Non-secretor } \\
\text { Non-secretor } \\
\text { Non-secretor }\end{array}$ & $\mathrm{pT} 1$ & $\begin{array}{l}\mathbf{M} \\
\mathbf{M} \\
\mathbf{M} \\
\mathbf{M} \\
\mathbf{M} \\
\mathbf{M} \\
\mathbf{M} \\
\mathbf{P} \\
\mathbf{M} \\
\mathbf{M} \\
\mathbf{P} \\
\mathbf{P} \\
\mathbf{M}\end{array}$ & $\begin{array}{l}M \\
\mathbf{S} \\
\mathbf{S} \\
\mathbf{M} \\
\mathbf{M} \\
\mathbf{M} \\
\mathbf{M}^{\mathrm{r}, \text { tu }} \\
\mathbf{M} \\
\mathbf{S} \\
\mathbf{M} \\
\mathbf{S}^{\mathrm{r}, \mathrm{tu}} \\
\mathbf{M}^{\mathrm{r}, \text { tu }} \\
\mathbf{M}\end{array}$ & $\begin{array}{l}1 \\
0-4 \\
0-4 \\
0-4 \\
0-3^{b} \\
0 \\
0 \\
0 \\
0 \\
0 \\
0 \\
0 \\
0\end{array}$ & $\begin{array}{l}0 \\
0-1 \\
0 \\
0 \\
0-2^{b} \\
0 \\
0 \\
0 \\
0-2 \\
0 \\
0 \\
0 \\
0\end{array}$ & $\begin{array}{l}4 \\
4 \\
1-2 \\
3\end{array}$ & $\begin{array}{l}0 \\
2 \\
1-2 \\
0 \\
0\end{array}$ \\
\hline $\begin{array}{l}66 \text { (Hed) } \\
67 \text { (Pid) } \\
68 \text { (Cook) } \\
69 \text { (Wal) } \\
70 \text { (Hog) } \\
71 \text { (Pas) } \\
72 \text { (Lym) } \\
73 \text { (Tho) }\end{array}$ & $\begin{array}{l}\mathbf{M} \\
\mathbf{M} \\
\mathbf{F} \\
\mathbf{M} \\
\mathbf{M} \\
\mathbf{M} \\
\mathbf{M} \\
\mathbf{M}\end{array}$ & $\begin{array}{l}61 \\
84 \\
79 \\
65 \\
88 \\
72 \\
89 \\
74\end{array}$ & $\begin{array}{l}\text { Secretor } \\
\text { Secretor } \\
\text { Secretor } \\
\text { Secretor } \\
\text { Non-secretor } \\
\text { Secretor } \\
\text { Not determined } \\
\text { Secretor }\end{array}$ & $\mathrm{pT} 2$ or $>$ & $\begin{array}{l}M \\
P \\
P \\
M \\
M \\
P \\
P \\
P\end{array}$ & $\begin{array}{l}\mathbf{S} \\
\mathbf{S} \\
\mathbf{S} \\
\mathbf{S} \\
\mathbf{M} \\
\mathbf{S}^{\mathrm{r}} \text { tu } \\
\mathbf{S} \\
\mathbf{S}\end{array}$ & $\begin{array}{l}0-4^{b} \\
0-3 \\
0 \\
0 \\
0 \\
0 \\
0 \\
0\end{array}$ & $\begin{array}{l}0 \\
0 \\
0 \\
0 \\
(0)-2 \\
2 \\
0-(2) \\
0\end{array}$ & 3 & $3-4$ \\
\hline
\end{tabular}

*W, $\mathrm{M}$, and $\mathrm{P}=$ well, moderately, and poorly differentiated tumours, respectively; asterisk indicates absence of muscle in biopsy specimens used for histological assessment.

$\dagger \mathbf{S}=$ single tumour present; $\mathbf{M}=$ multiple tumours present; in the invasive tumours, all of which were solitary, $\mathbf{M}$ indicates the additional presence of multiple superficial tumours. The latter were not studied. Superscript $r$ indicates recurrent tumour, otherwise the tumours were examined at first presentation; superscripts tu and ct indicate previous treatment by transurethral resection and intravesical chemotherapy, respectively.

$\ddagger$ Fluorescence intensity was graded $0-4$ and parentheses are used for areas corresponding to less than about $5 \%$ as described in the material and methods section; superscript $b$ indicates fluorescence predominantly in tumour cells surrounding blood vessels and connective tissue. $\S A=$ Immunofluorescence with polyclonal anti-A serum; $\mathbf{H}=$ fluorescence with Ulex europaeus lectin.

$\|$ Superscript ab indicates subjects of AB blood group.

M Watkins) followed by fluorescein isothiocyanate conjugated goat antirabbit IgG (Cappel Laboratories, Cochranville, Pennsylvania 19330, United States, purchased from Dynatech Laboratories Ltd, Billingshurst, Sussex). Ulex lectin in the presence of $20 \mathrm{mM}$ fucose or normal rabbit serum were used as negative controls. The sections were then fixed in phosphate buffered saline (PBS) containing $4 \%(w / v)$ formaldehyde. For viewing they were mounted in PBS:glycerol, 1:9 (v/v) containing $0.22 \mathrm{M}$ 1,4-diazabicyclo-(2,2,2)-octane, pH 8.6. ${ }^{17}$ Sections were viewed independently by two of us (SJT and TF) without knowledge of the histopathological stage or grade of the tumours, using a Zeiss epifluorescence microscope, and the intensity of fluorescence above control was graded from weak (score 1) to strong (score 4). In the final analysis of antigen expression tumours with traces of antigen fluorescence restricted 
Table 3 Age, sex, blood group, secretor status (where known), histology of tumours and fluorescence of tumours and non-neoplastic urothelia of patients with miscellaneous urothelial tumours

\begin{tabular}{|c|c|c|c|c|c|c|c|c|c|c|c|}
\hline \multirow{3}{*}{$\begin{array}{l}\text { Case } \\
\text { No }\end{array}$} & \multirow[b]{3}{*}{ Sex } & \multirow[b]{3}{*}{ Age } & \multirow{3}{*}{$\begin{array}{l}\text { Blood } \\
\text { group }\end{array}$} & \multirow{3}{*}{$\begin{array}{l}\text { Secretor } \\
\text { status }\end{array}$} & \multirow{2}{*}{\multicolumn{3}{|c|}{ Histology of tumour }} & \multicolumn{4}{|c|}{ Fluorescence $\ddagger$} \\
\hline & & & & & & & & \multicolumn{2}{|c|}{ Tumour } & \multicolumn{2}{|c|}{$\begin{array}{l}\text { Non-neoplastic } \\
\text { urothelium }\end{array}$} \\
\hline & & & & & Stage & Grade* & Multiplicity† & $A$ & $H$ & $A$ & $H$ \\
\hline $\begin{array}{l}74 \text { (Ait) } \\
75 \text { (Air) } \\
76 \text { (ForD) } \\
77 \text { (Lai) } \\
78 \text { (Phi) } \\
79 \text { (Har) }\end{array}$ & $\begin{array}{l}\mathbf{F} \\
\mathbf{M} \\
\mathbf{M} \\
\mathbf{M} \\
\mathbf{M} \\
\mathbf{M}\end{array}$ & $\begin{array}{l}74 \\
82 \\
58 \\
59 \\
81 \\
85\end{array}$ & $\begin{array}{l}\text { A } \\
\text { A } \\
\text { A } \\
\text { O } \\
\text { A } \\
\text { O }\end{array}$ & $\begin{array}{l}\quad \text { Upper uroth } \\
\text { Not determined } \\
\text { Secretor } \\
\text { Not determined } \\
\text { Non-secretor } \\
\text { Not determined } \\
\text { Not determined }\end{array}$ & $\begin{array}{l}\text { ial tract } \\
\text { pTa } \\
\text { pTa } \\
\text { pTa } \\
\text { pTa } \\
\text { pT1 } \\
\text { pT1 }\end{array}$ & $\begin{array}{l}\text { ansitional } \\
\mathbf{M} \\
\mathbf{M} \\
\mathbf{M} \\
\mathbf{M} \\
\mathbf{M} \\
\mathbf{M}\end{array}$ & $\begin{array}{l}\text { cell carcinomas: } \\
\mathbf{M} \\
\mathbf{S} \\
\mathbf{S} \\
\mathbf{M}^{\text {r. tu, at }} \\
\mathbf{S} \\
\mathbf{S}\end{array}$ & $\begin{array}{l}(1)-4 \\
0-4 \\
0-(2) \\
0\end{array}$ & $\begin{array}{l}0-(1) \\
0 \\
0-(1) \\
0-(1) \\
0 \\
1\end{array}$ & $\begin{array}{l}4 \\
3-4 \\
3\end{array}$ & $\begin{array}{l}2 \\
0-3 \\
0\end{array}$ \\
\hline $\begin{array}{l}80 \text { (Dow) } \\
81 \text { (''Ha) }\end{array}$ & $\begin{array}{l}\mathbf{F} \\
\mathbf{F}\end{array}$ & $\begin{array}{l}78 \\
69\end{array}$ & $\begin{array}{l}\mathrm{A} \\
\mathrm{O}\end{array}$ & $\begin{array}{l}\text { Squame } \\
\text { Secretor } \\
\text { Secretor }\end{array}$ & $\begin{array}{l}\text { s cell ca } \\
\text { pT3b\$ } \\
\text { pT3a§ }\end{array}$ & $\begin{array}{c}\text { inomas of } \\
\mathbf{M} \\
\mathbf{M}\end{array}$ & $\begin{array}{l}\text { the bladder: } \\
\text { S } \\
\text { S }\end{array}$ & 0 & $\begin{array}{l}3 \\
0-4\end{array}$ & 4 & 1 \\
\hline \multicolumn{12}{|c|}{ Adenocarcinoma of the bladder: } \\
\hline
\end{tabular}

$* \mathrm{~W}, \mathrm{M}$, and $\mathbf{P}=$ well, moderately, and poorly differentiated tumours, respectively; asterisk indicates absence of muscle in biopsy specimens used for histological assessment.

$\mathrm{tS}=$ single tumour present; $\mathbf{M}=$ multiple tumours present; in the invasive tumours, all of which were solitary, $\mathbf{M}$ indicates the additional presence of multiple superficial tumours. The latter were not studied. Superscript $r$ indicates recurrent tumour, otherwise the tumours were examined at first presentation; superscripts tu and ct indicate previous treatment by transurethral resection and intravesical chemotherapy, respectively.

$\ddagger$ Fluorescence intensity was graded $0-4$ and parentheses are used for areas corresponding to less than about $5 \%$ as described in the material and methods section; superscript $b$ indicates fluorescence predominantly in tumour cells surrounding blood vessels and connective tissue. \$Indicates presence of fat in biopsy specimens used for histological assessment.

to less than about $5 \%$ of the tumour were scored as being antigen negative (designated $\mathrm{H}-$ or $\mathrm{A}-$ ). Tumours with extensive antigen fluorescence were designated $\mathrm{H}+$ or $\mathrm{A}+$ : those with focal antigen expression were designated $\mathrm{H} \pm$ or $\mathrm{A} \pm$. Fluorescence and phase contrast photomicrographs were taken using Ilford HP5 and Panatomic X films, respectively.

Assessment of the expression of the blood group $\mathrm{H}$ antigen in the bladder tumours both of group $\mathrm{O}$ and A subjects proved difficult using the polyclonal anti-H serum used in our previous study. ${ }^{10}$ Non-neoplastic epithelia gave clear cut fluorescence, but most of the bladder tumours gave a diffuse fluorescence of varying intensity. This contrasted with the well defined immunofluorescence patterns that have been obtained $^{16}$ using this antiserum with normal and neoplastic gastric tissues. On the other hand, clear patterns of fluorescence, inhibitable with $20 \mathrm{mM}$ fucose, were observed with Ulex europaeus lectin: the assessment of $\mathrm{H}$ antigen expression in this study was therefore performed with the lectin. Expression of the blood group $\mathrm{A}$ antigen was satisfactorily assessed using the polyclonal anti-A serum. Using this reagent clear cut fluorescence patterns could be discerned in the non-neoplastic mucosae and in the tumours of the group $\mathrm{A}$ but not in those of blood group $\mathrm{O}$ patients.

\section{Results}

Tables 1-3 give details of the patient, and histo- logical and fluorescence data on their tumours Samples of non-neoplastic urothelium from 26 of the patients were available, and their results are also shown.

\section{NON-NEOPLASTIC BLADDER MUCOSAE OF}

\section{PATIENTS WITH UROTHELIAL CARCINOMAS}

There was moderate or strong fluorescence of the blood group $\mathrm{H}$ or A antigen, respectively, in the nonneoplastic mucosae examined from secretors of blood group $O$ (five cases, table 1) and blood group A (12 cases, tables 2 and 3). Eight of these blood group A patients also showed blood group $\mathrm{H}$ fluorescence. Only three samples from known non-secretors were available; in accordance with earlier observations, ${ }^{10}$ two of these showed only weak fluorescence of $\mathrm{H}$ antigen (group $\mathrm{O}$ subject) or $\mathrm{A}$ antigen (group $\mathrm{A}$ subject).

\section{TRANSITIONAL CELL CARCINOMAS OF THE} BLADDER

Correlation of antigen expression with histopathological stage

(i) Tumours of pTa stage Blood group $\mathrm{H}$ antigen was expressed throughout only one of the 15 tumours from group $O$ patients and the $A$ antigen throughout 10 of the 19 tumours from those of group A (table 4). A spectrum of reactivities, with focal areas of loss of the appropriate antigen, was observed in nine of the group $\mathrm{O}$ and five of the group $\mathrm{A}$ tumours of this stage. Thus as a group 25 of the 34 tumours (74\%) retained 
Table 4 Correlation of pathological stage with fluorescence of $H$ antigen in tumours of blood group $O$ patients and $A$ antigen in tumours of blood group A patients

\begin{tabular}{|c|c|c|c|c|c|}
\hline \multirow[b]{3}{*}{ Stage } & \multirow[b]{3}{*}{ Blood group } & \multicolumn{4}{|l|}{ No of cases } \\
\hline & & \multirow[b]{2}{*}{ No in group } & \multicolumn{3}{|c|}{ Fluorescence* } \\
\hline & & & + & \pm & - \\
\hline \multirow[t]{3}{*}{$\mathrm{pTa}$} & $\begin{array}{l}\mathbf{O} \\
\mathbf{A}\end{array}$ & $\begin{array}{l}15 \\
19\end{array}$ & $\begin{array}{r}1 \\
10\end{array}$ & $\begin{array}{l}9 \\
5\end{array}$ & $\begin{array}{l}5 \\
4\end{array}$ \\
\hline & Total & 34 & $11(32)$ & $14(41)$ & $9(26)$ \\
\hline & & \multicolumn{4}{|c|}{$25(74)$} \\
\hline \multirow[t]{3}{*}{ pT1 } & $\begin{array}{l}\mathrm{O} \\
\mathrm{A}\end{array}$ & $\begin{array}{r}6 \\
13\end{array}$ & $\begin{array}{l}1 \\
1\end{array}$ & $\begin{array}{l}3 \\
4\end{array}$ & $\begin{array}{l}2 \\
8\end{array}$ \\
\hline & Total & 19 & $2(11)$ & $7(37)$ & $10(53)$ \\
\hline & & \multicolumn{4}{|c|}{$9(47)$} \\
\hline \multirow[t]{3}{*}{ pT2 or $>$} & $\begin{array}{l}\mathrm{O} \\
\mathrm{A}\end{array}$ & $\begin{array}{r}12 \\
8\end{array}$ & $\begin{array}{l}5 \\
0\end{array}$ & $\begin{array}{l}1 \\
2\end{array}$ & $\begin{array}{l}6 \\
6\end{array}$ \\
\hline & Total & 20 & $5(25)$ & $3(15)$ & $12(60)$ \\
\hline & & \multicolumn{4}{|c|}{$8(40)$} \\
\hline
\end{tabular}

* + = fluorescence of appropriate antigen - that is, $\mathrm{H}$ antigen in group $\mathrm{O}$ patients and $\mathrm{A}$ antigen in group $\mathrm{A}$ patients-throughout the tumour; $\pm=$ fluorescence in some areas and complete lack of fluorescence in others; - = lack of fluorescence throughout the tumour, except in endothelia.

Figures in parentheses indicate percentage of cases in each group.

substantial amounts of the appropriate antigen. The remaining tumours $(26 \%$; five from group $\mathrm{O}$ and four from group A patients) lacked the appropriate antigen. The $\mathrm{H}$ antigen was expressed in only one of these four A antigen negative tumours (table 5).

(ii) Tumours of pT1 stage Of the pT1 stage tumours, one of the six from group $O$ patients and one of the 13 from the group A patients expressed the appropriate antigen throughout (table 4); three from group $\mathrm{O}$ and four from group A patients showed focal areas of $\mathbf{H}$ or A antigen loss, respectively. Thus nine of the 19 tumours $(47 \%)$ of pT1 stage retained substantial amounts of the appropriate antigen while the remaining $10(53 \%)$ did not. Only one of the eight $\mathrm{A}$ antigen negative tumours of this stage showed blood group $\mathrm{H}$ reactivity (table 5 ).

(iii) Tumours of $p T 2$ or greater stage Of the invasive tumours of pT2 or greater stage, five of the 12 from group $O$ patients but none of the eight group $A$ tumours expressed the appropriate antigen throughout (table 4). One tumour from a group $\mathrm{O}$ patient and two from group A patients showed focal areas of loss of the corresponding antigen. Thus eight of the 20 tumours $(40 \%)$ of this stage retained substantial amounts of the appropriate antigen, whereas 12 $(60 \%)$ did not; of the six A antigen negative tumours, two showed blood group $\mathrm{H}$ fluorescence (table 5).

Thus, overall, a lack of the genetically predicted $\mathrm{H}$ or A antigens was twice as common in both pT1 and pT2 or greater stages than in those of pTa stage. $\mathrm{H}$ antigen expression was not necessarily associated with $\mathrm{A}$ antigen loss (table 5). Of the tumours from group A subjects, extensive $\mathrm{H}$ antigen fluorescence $(\mathrm{H}+)$ was detected in only two of the $18 \mathrm{~A}$ antigen negative tumours $(\mathrm{A}-)$ (table 5). Focal expression of this antigen $(\mathrm{H} \pm)$ was detected in one of the 11 tumours designated $\mathrm{A}+$ and four of the 11 tumours designated $\mathrm{A} \pm$.

\section{Correlation of antigen expression and differentiation grade}

Table 6 analyses the expression of the $\mathrm{H}$ and $\mathrm{A}$ antigens in tumours of group $O$ and $A$ patients, respectively, in relation to differentiation grade. The only sample of well differentiated tumour included in this study was antigen negative. Thirty five per cent of the moderately well differentiated tumours and $65 \%$ of the poorly differentiated tumours were scored as antigen negative. Thus, overall, antigen loss was roughly twice as common among the poorly differentiated tumours as among the moderately differentiated tumours.

Correlation of antigen expression with secretor status Of the bladder tumours examined, 42 were from known secretors and 11 from non-secretors (tables 1 and 2). As with the non-neoplastic bladder mucosae, higher fluorescence scores for the $\mathrm{H}$ and $\mathrm{A}$ antigens were found among secretors (score range 0-4) than 
Table 5 Correlation of expression of $\boldsymbol{H}$ antigen with $A$ antigen in transitional cell carcinomas of bladder of blood group $A$ subjects

\begin{tabular}{|c|c|c|c|c|}
\hline \multirow{2}{*}{$\begin{array}{l}\text { Tumour grade and } \\
\text { secretor status }\end{array}$} & \multirow{2}{*}{$\begin{array}{l}\text { Fluorescence of } \\
\text { A antigen }\end{array}$} & \multicolumn{3}{|c|}{$\begin{array}{l}\text { Fluorescence of } H \text { antigen* } \\
\text { No of cases }\end{array}$} \\
\hline & & $H+$ & $H \pm$ & $H-$ \\
\hline $\begin{array}{l}\text { Secretors: } \\
\text { pTa }\end{array}$ & $\begin{array}{l}\mathrm{A}+ \\
\mathrm{A} \pm \\
\mathrm{A}-\end{array}$ & & $\begin{array}{l}1 \\
1\end{array}$ & $\begin{array}{l}8 \\
2\end{array}$ \\
\hline pT1 & $\begin{array}{l}\mathrm{A}+ \\
\mathrm{A} \pm \\
\mathrm{A}-\end{array}$ & & 1 & $\begin{array}{l}2 \\
1\end{array}$ \\
\hline pT2 or $>$ & $\begin{array}{l}\mathrm{A}+ \\
\mathrm{A} \pm \\
\mathrm{A}-\end{array}$ & 1 & & 2 \\
\hline $\begin{array}{l}\text { Non-secretors: } \\
\text { pTa }\end{array}$ & $\begin{array}{l}A \pm+ \\
A \pm\end{array}$ & & & \\
\hline pT1 & $\begin{array}{l}A- \\
A+ \\
A \pm \\
A-\end{array}$ & & & $\begin{array}{l}2 \\
1 \\
5\end{array}$ \\
\hline pT2 or $>$ & $\begin{array}{l}A+ \\
A \pm \\
A-\end{array}$ & 1 & & J \\
\hline $\begin{array}{l}\text { Not determined: } \\
\text { pTa }\end{array}$ & $\begin{array}{l}\mathrm{A}+ \\
\mathrm{A} \pm \\
\mathrm{A}-\end{array}$ & & 2 & $\begin{array}{l}1 \\
1 \\
1\end{array}$ \\
\hline $\mathrm{pT} 1$ & $\begin{array}{l}\mathrm{A}+ \\
\mathrm{A} \pm \\
\mathrm{A}-\end{array}$ & & 1 & 1 \\
\hline pT2 or $>$ & $\begin{array}{l}\mathrm{A}+ \\
\mathrm{A} \pm \\
\mathrm{A}-\end{array}$ & & & 1 \\
\hline Total & $\begin{array}{l}\mathbf{A}+ \\
\mathbf{A} \pm \\
\mathbf{A}-\end{array}$ & $\begin{array}{l}0 \\
0 \\
2\end{array}$ & $\begin{array}{l}1 \\
4 \\
2\end{array}$ & $\begin{array}{r}10 \\
7 \\
14\end{array}$ \\
\hline
\end{tabular}

*The symbols after $\mathrm{A}$ or $\mathrm{H}$ indicate fluorescence of these antigens in all areas $(+)$, in focal areas $( \pm)$, or a lack of fluorescence $(-)$.

Table 6 Correlation of tumour grade with fluorescence of $H$ antigen in tumours of blood group $O$ patients and $A$ antigen in tumours of blood group A patients

\begin{tabular}{|c|c|c|c|c|c|}
\hline \multirow[b]{2}{*}{ Grade } & \multirow[b]{2}{*}{ Blood group } & \multirow[b]{2}{*}{ No in group } & \multicolumn{3}{|c|}{ Fluorescence ${ }^{*}$} \\
\hline & & & + & \pm & - \\
\hline Well & $\begin{array}{l}\mathbf{O} \\
\mathbf{A}\end{array}$ & $\begin{array}{l}1 \\
0\end{array}$ & $\begin{array}{l}0 \\
0\end{array}$ & $\begin{array}{l}0 \\
0\end{array}$ & $\begin{array}{l}1 \\
0\end{array}$ \\
\hline \multirow[t]{3}{*}{ Moderate } & $\begin{array}{l}\mathbf{O} \\
\mathbf{A}\end{array}$ & $\begin{array}{l}24 \\
31\end{array}$ & $\begin{array}{r}4 \\
11\end{array}$ & $\begin{array}{r}12 \\
9\end{array}$ & $\begin{array}{r}8 \\
11\end{array}$ \\
\hline & Total & 55 & $15(27)$ & $21(38)$ & $19(35)$ \\
\hline & & \multicolumn{4}{|c|}{$36(65)$} \\
\hline \multirow[t]{3}{*}{ Poor } & $\begin{array}{l}\mathbf{O} \\
\mathbf{A}\end{array}$ & $\begin{array}{l}8 \\
9\end{array}$ & $\begin{array}{l}3 \\
0\end{array}$ & $\begin{array}{l}1 \\
2\end{array}$ & $\begin{array}{l}4 \\
7\end{array}$ \\
\hline & Total & 17 & $3(18)$ & $3(18)$ & $11(65)$ \\
\hline & & \multicolumn{4}{|c|}{$6(35)$} \\
\hline
\end{tabular}



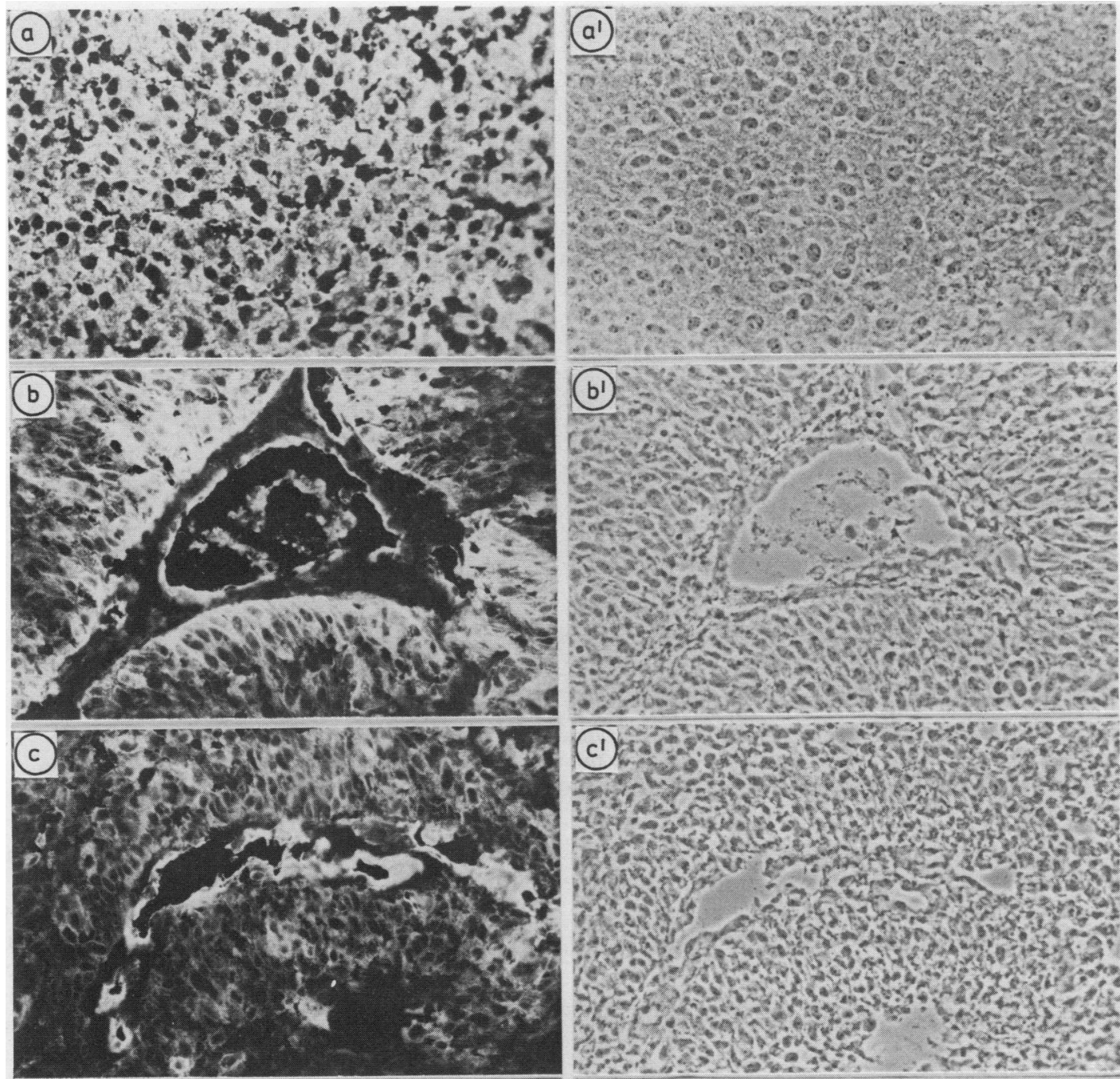

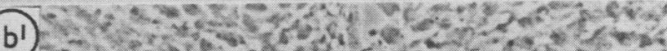

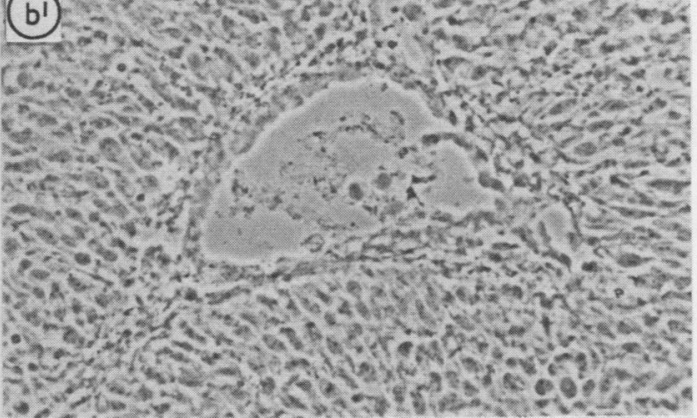

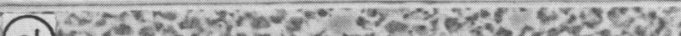

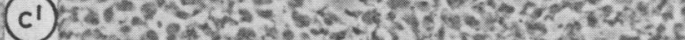
c. cos.

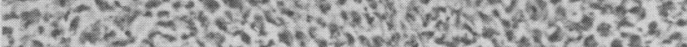

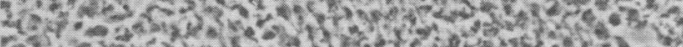

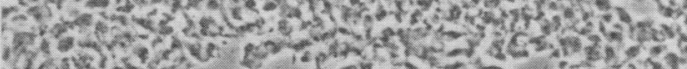
(1) 30 ? r.

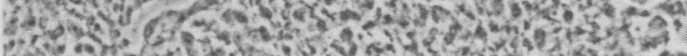
(s)

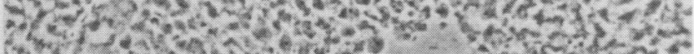

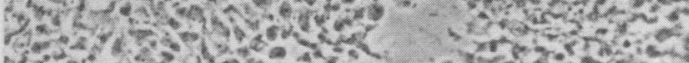
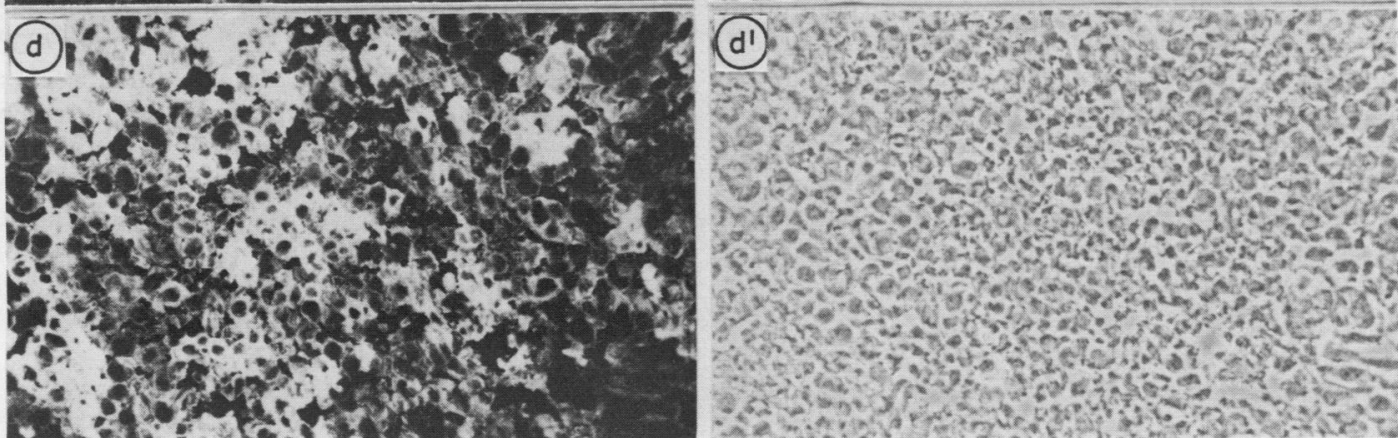

Fig 1 Three different patterns of immunofluorescence of blood group $A$ antigen, using rabbit anti-A serum, in transitional cell carcinomas of bladder with antigen present throughout: panel a "even" pattern (case 35); panel b, basal pattern (case 39) showing strongest fluorescence in tumour cells adjacent to central blood vessel; panels $c$ and d, random pattern (case 40 and 37) showing irregular distribution of most brightly fluorescent tumour cells. Panels $a^{\prime}-d$ ' show corresponding phase contrast micrographs. Original magnification $\times 350$. 

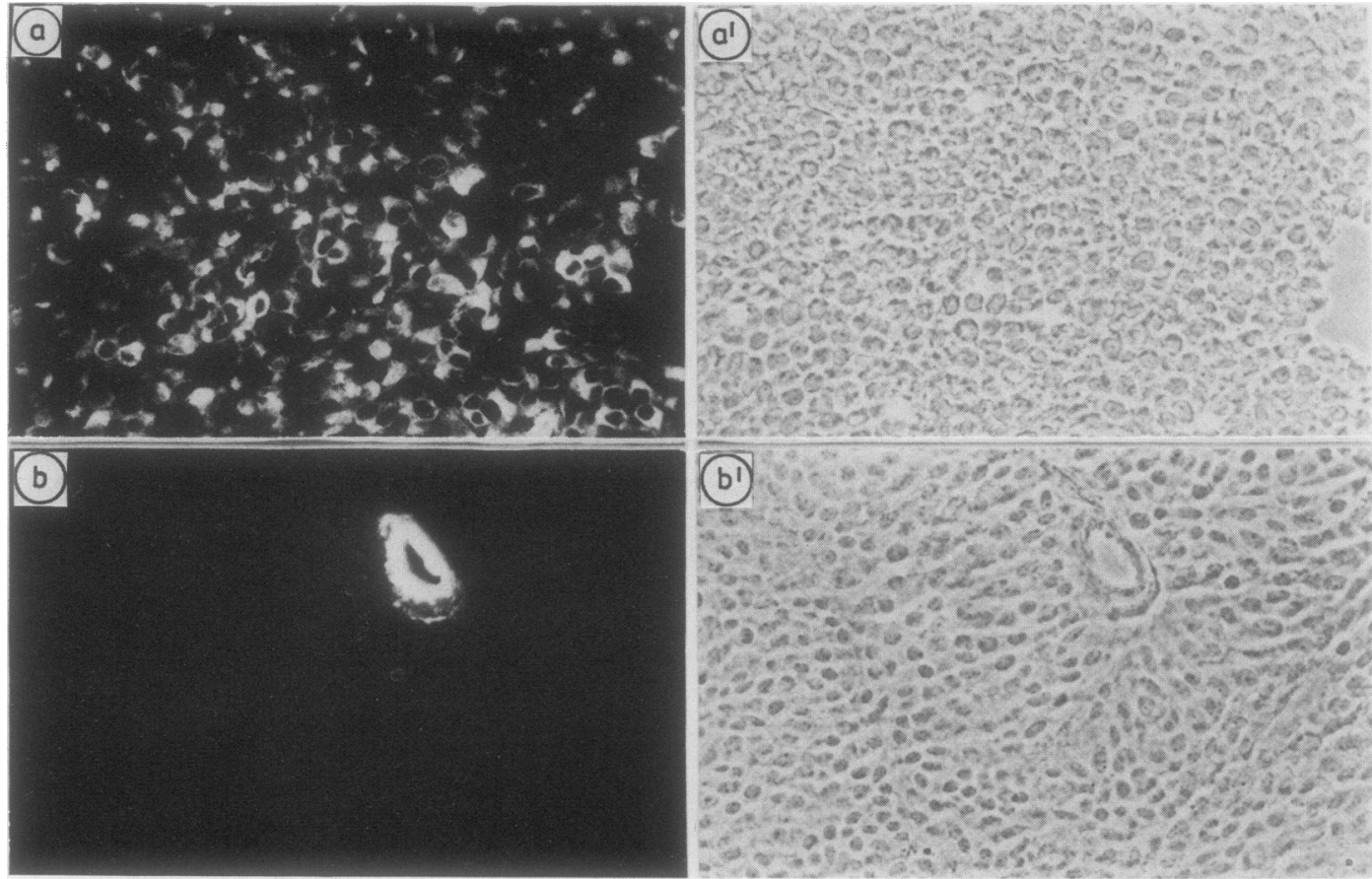

Fig 2 Immunofluorescence of blood group A antigen, using rabbit anti-A serum, in transitional cell carcinomas of bladder: panel a, randomly distributed antigen positive and antigen negative tumour cells (case 54); panel b, antigen negative tumour in which only endothelium of small blood vessel is showing immunofluorescence (case 51). Original magnification $\times 350$.

among non-secretors (range $0-2$ ). Moreover, a total loss of the $\mathrm{H}$ or $\mathrm{A}$ antigen was more commonly observed among tumours of non-secretors (nine of 11 cases; $82 \%$ ) than among those of secretors (15 of 42 cases; $36 \%$ ).

\section{Correlation of antigen expression with multiplicity of tumours}

Complete antigen loss was observed more commonly in samples from patients with multiple superficial tumours of pTa and pT 1 stages $(10$ of $21 ; 48 \%)$ and in single invasive tumours accompanied by multiple superficial tumours (three of three) than in single superficial (nine of $32 ; 28 \%$ ) or invasive (nine of 17 ; $53 \%$ ) tumours, respectively (tables 1 and 2). Antigen expression in the superficial tumours accompanying invasive tumours was not studied.

\section{Distribution of $H$ and $A$ antigens within tumours}

Four main patterns of fluorescence of the $\mathrm{H}$ and $\mathrm{A}$ antigens were observed in the tumours: (i) fluorescence of relatively even intensity throughout the tumour (fig 1a); (ii) fluorescence throughout the tumour but with variation in intensity from area to area or from cell to cell (figs 1b-d); (iii) fluorescence in some areas and a lack of fluorescence in others (figs $2 a$ and 3a-d); and (iv) complete lack of fluorescence throughout the tumour (fig $2 b$ ).

In categories (ii) and (iii) the most strongly stained tumour cells were either apparently randomly distributed (random pattern; figs 1c, d, and 2a) or were located around blood vessels and adjacent connective tissues (basal pattern; figs $1 \mathrm{~b}$ and $3 \mathrm{a}-\mathrm{d}$ ). The basal pattern was most often observed among the tumours of pTa stage (20 of $26 ; 77 \%)$. Four of eight $(50 \%)$ tumours of pT1 stage and three of nine $(33 \%)$ tumours of pT2 or higher stage showed the basal pattern of fluorescence. A comparison of the fluorescence pattern with tumour grade showed that the basal pattern was twice as common among moderately well differentiated tumours (24 of 36 antigen positive tumours; $(66 \%)$ showed this pattern) as among poorly differentiated tumours (two of seven antigen positive tumours; $29 \%$ ).

\section{OTHER TUMOURS OF THE UROTHELIUM}

The blood group $\mathrm{H}$ and $\mathrm{A}$ antigens were assessed in nine additional tumours of the urothelium (table 3). Of six transitional cell carcinomas of the upper urothelial tract, all of which were at superficial pTa or pT1 stages, complete loss of the genetically predicted $\mathrm{H}$ or $\mathrm{A}$ antigen was observed in three. Of the two 

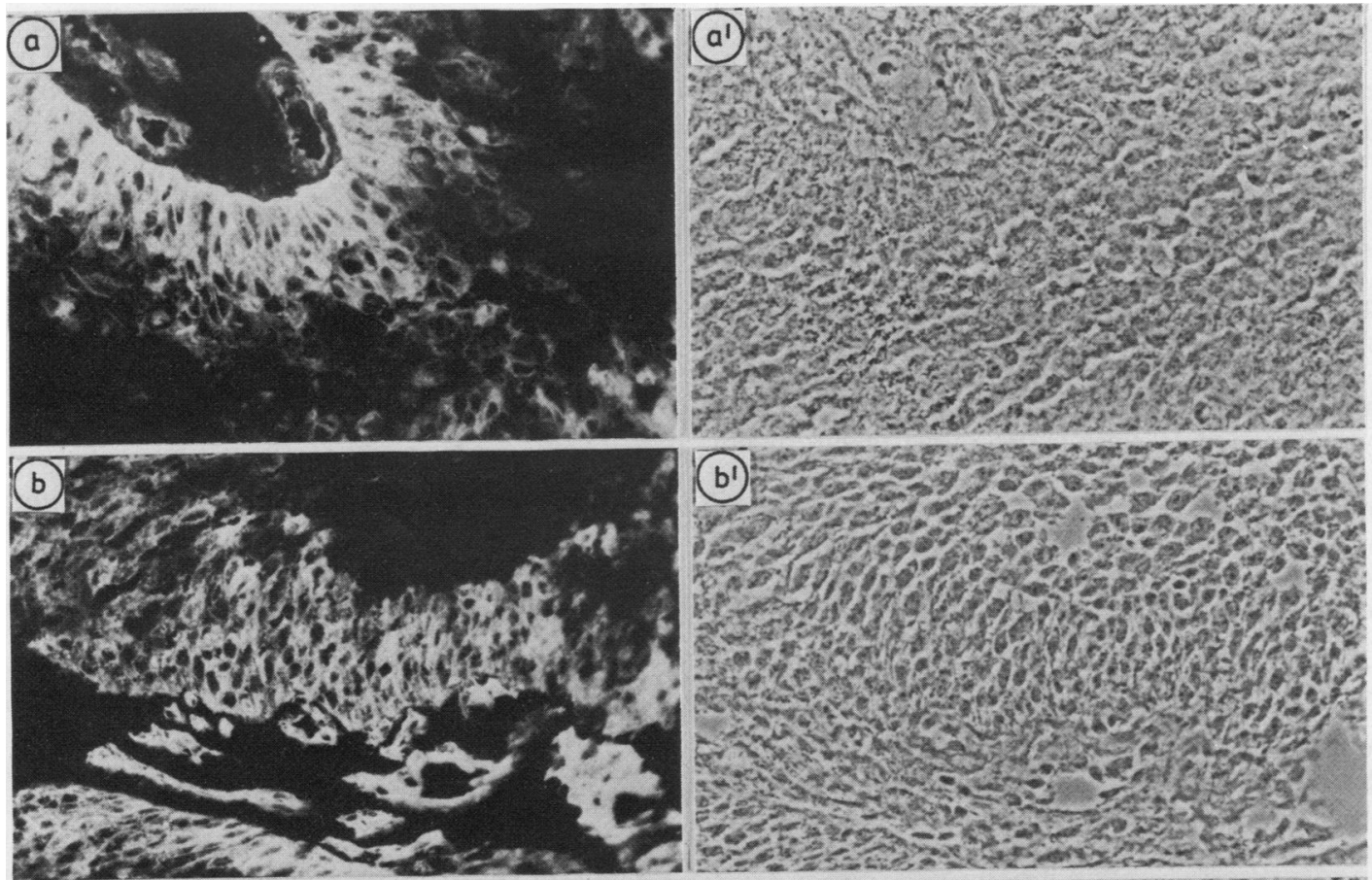

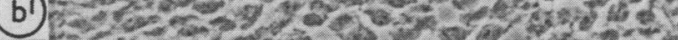

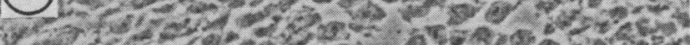

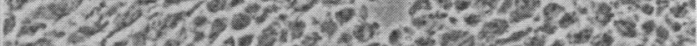

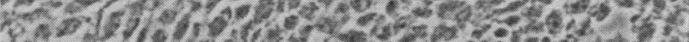

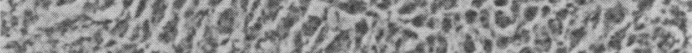
Sol.t2

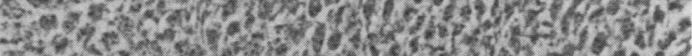
संक्ष.

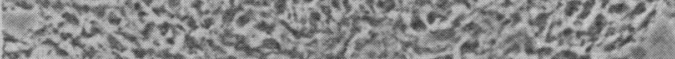
C.

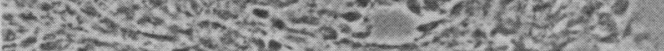

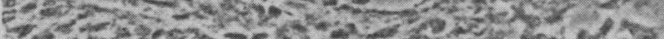
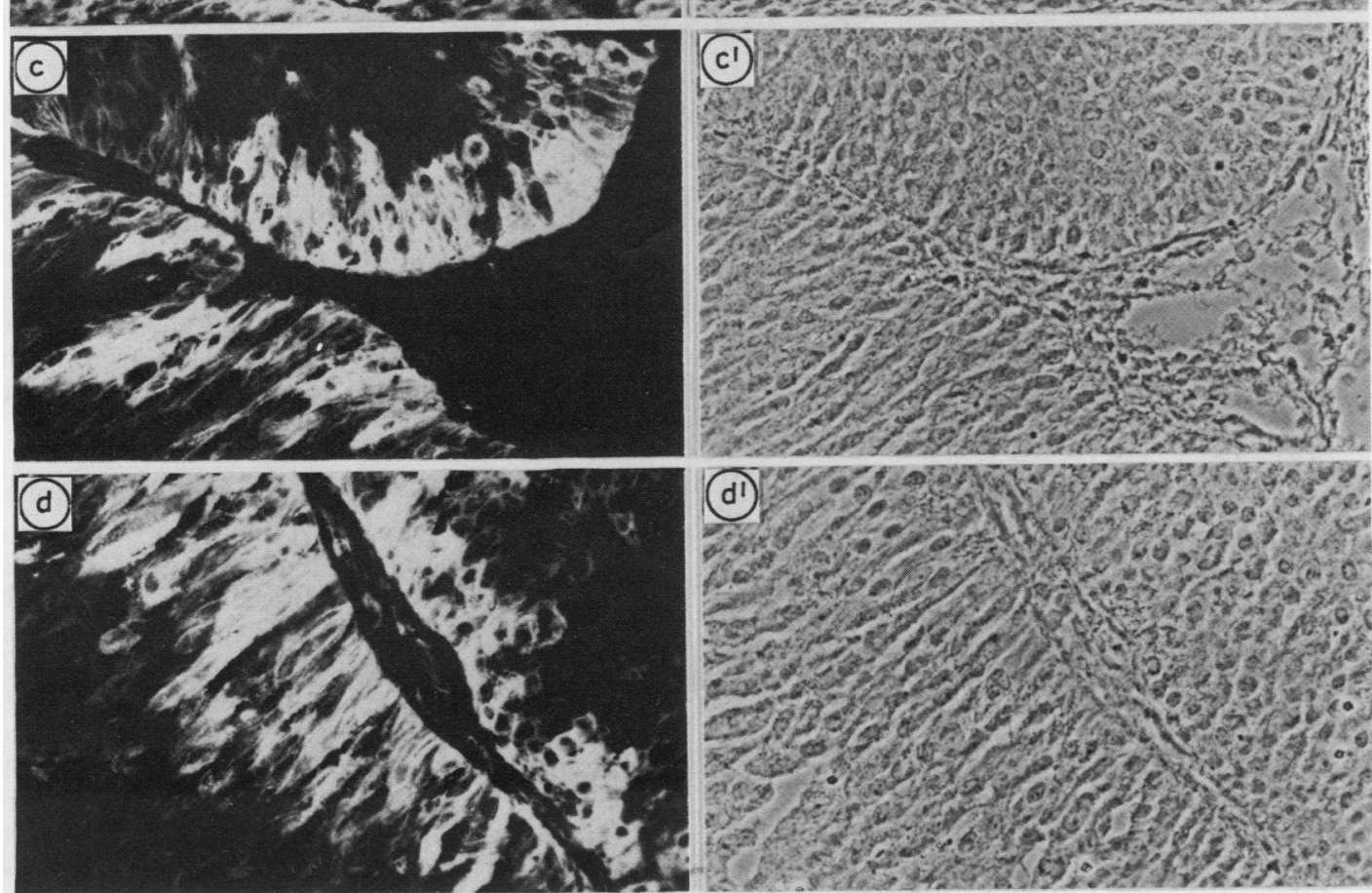
(d) 20 s.

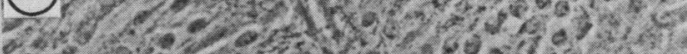

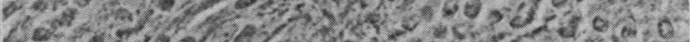

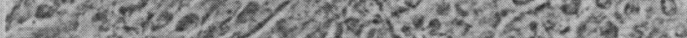

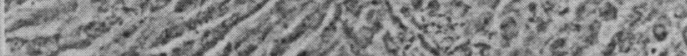

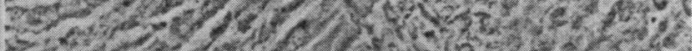

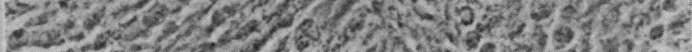

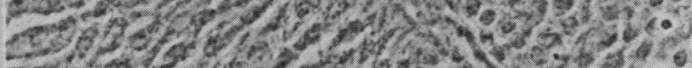

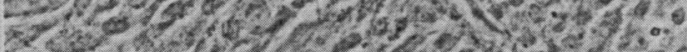

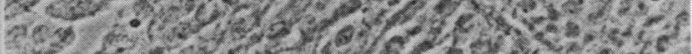

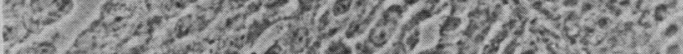

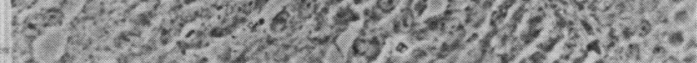

Fig 3 Basal pattern of blood group antigen fluorescence in transitional cell carcinomas of bladder with focal antigen loss, obtained using Ulex europaeus lectin (panel a, case 17) or rabbit anti-A serum (panel b, case 44; panels $c$ and d, case 57). Original magnification $\times 350$. 
cases of squamous cell carcinoma of the bladder, both of which were invading muscle, one showed a complete lack and the other showed focal lack of the appropriate blood group antigen. Blood group $\mathbf{H}$ antigen fluorescence of uneven intensity was observed in the muscle invasive adenocarcinoma of bladder.

\section{Discussioṇ}

The main objective of this prospective study has been to resolve conflicting data on the degrees and patterns of expression of the blood group $\mathrm{H}$ and $\mathrm{A}$ antigens in transitional cell carcinomas of the bladder by using cryostat sections of fresh frozen rather than formalin fixed paraffin embedded tissues, thus minimising antigen extraction during tissue processing. With a few exceptions tumour tissue was studied at first presentation; correlation of antigen expression with the subsequent course of the tumours will be the subject of a future study.

There were 73 cases of transitional cell carcinoma of the bladder. Using the polyclonal rabbit antiblood group A serum with tumours of group A subjects and Ulex europaeus lectin with the tumours of group $\mathrm{O}$ subjects, we found that, overall, antigen loss was roughly twice as common in poorly differentiated tumours $(65 \%)$ as in moderately well differentiated tumours $(35 \%)$, and twice as common in tumours of pT1 or higher stages $(53 \%$ in pT1 and $60 \%$ in muscle invading tumours) as in those of pTa stage (26\%). This is somewhat surprising as pT1 tumours are considered to be superficial. When blood group was taken into account, we note that there was a higher incidence of antigen loss $(62 \%)$ among pT1 stage tumours of group A subjects than of group O subjects $(33 \%)$. The numbers in each group, however, are too small to attach immediate importance to these differences, and the relevance of these differences to the subsequent course of the tumours remains to be determined. Thus no obvious antigenic features were found that correlated closely with invasive stage or differentiation grade. This also applied to the miscellaneous urothelial tumours included in this study.

Two major factors complicated the assessment of the antigen state of the bladder tumours. The first was the considerable heterogeneity of antigen expression within tumours; in only three of the $\mathbf{4 6}$ antigen positive tumours in this study (about $7 \%$ ) was there an even distribution of the appropriate $\mathbf{H}$ or $\mathbf{A}$ antigen (tables 1 and 2). The second complicating factor was the lower level of antigen expression in the normal and neoplastic epithelium of non-secretors; thus $82 \%$ of the tumours from non-secretors but only $36 \%$ of those from secretors were antigen negative.

Preparation of tissues

Most previous studies of blood group antigen expres- sion in bladder tumours have used paraffin embedded sections as this allows retrospective studies to be performed. Most investigators do not seem to have taken into account the observation ${ }^{11}$ that substantial proportions of the blood group $\mathrm{A}, \mathrm{B}$, and $\mathrm{H}$ antigens of the urothelium are in alcohol soluble form (a property associated with glycolipids) and are extracted during processing of tissues before paraffin embedding. Several groups have reported on the difficulty in detecting the $\mathrm{H}$ antigen in paraffin embedded sections (using Ulex europaeus lectin and the red cell adherence test) resulting in false antigen negative tests with both normal and neoplastic urothelia from group $\mathrm{O}$ patients, ${ }^{1819}$ but they have tried to overcome the problem by increasing the sensitivity of antigen detection-for example, by using a Ulex-anti-Ulex immunoperoxidase technique. ${ }^{20-23}$

$\mathrm{We}^{10}$ and Limas and Lange ${ }^{512}$ showed conclusively that reliable assessment of blood group antigens can be made only on cryostat sections, and in this study we found no $\mathrm{H}$ antigen negative mucosae in blood group $\mathrm{O}$ subjects. Very few studies, however, have been carried out on material other than paraffin sections, and no prospective studies have been carried out using freshfrozen material as used in this study. Fujita et $\mathrm{l}^{8}$ used the red cell adherence test on formalin fixed cryostat sections and found no clear correlation between antigen expression and degree of malignancy. Kay and Wallace ${ }^{7}$ and Srinivas et $a^{24}$ used the red cell adherence test on single cell sus pensions from bladder tumours and normal urothelium. Kay and Wallace found no close correlation between antigen expression and tumour behaviour; Srinivas et al reported a good correlation of antigen expression with histological findings and the stage of disease. In view of the difficulties of ensuring the purity of suspensions of tumour cells we chose to carry out the present study with tissue sections.

\section{Assessment of antigen expression}

The pronounced regional and cell to cell variations in the amounts of blood group antigen made the histochemical quantitation of antigen expression in the tumours difficult. This variability, which was also noted in our earlier studies of gastric carcinomas, ${ }^{16}$ would greatly complicate quantitive analyses of single cell suspensions of biopsy material. In this histochemical study of cryostat sections we assessed antigen expression using three categories of antigen score: $(+)$ for antigen fluorescence in all areas, $( \pm)$ for antigen absence in focal areas, and $(-)$ for antigen lack in all or almost all (assessed as greater than 95\%) tumour areas. Although subjective, this scoring system presented no difficulty as we found that tumours either had substantial amounts of antigen staining (in roughly $20 \%$ or greater areas), or they were com- 
pletely or almost completely antigen negative. Antigen intensity, although recorded in tables $1-3$, was not noted in our final analysis, although it was obvious that many tumours had low intensities of antigen expression.

\section{Effect of secretor status}

In many secretory epithelia the blood group A, B, and $\mathrm{H}$ antigens are absent in $25 \%$ of the population who do not have the secretor gene and are termed nonsecretors. ${ }^{25}$ We have previously noted the importance of determining the secretor status of patients in assessing the tumour associated changes in the carbohydrate antigens of gastric and colonic adenocarcinomas. ${ }^{3626}$ Although these antigens are normally detectable in transitional epithelia of non-secretors as well as secretors, ${ }^{11}$ the amounts in the bladder epithelium of non-secretors are lower. ${ }^{10}$ This is an important additional consideration in the assessment of tumour associated changes in antigen expression. In this and an earlier study ${ }^{12}$ antigen reduction was more pronounced in the tumours from non-secretors. Moreover, a detailed study by $\mathrm{Juhl}^{27}$ has shown that when paraffin embedded sections are used, the $\mathrm{A}$ and $\mathrm{H}$ antigens are usually not detectable in the normal urothelium of $\mathrm{Le}^{\mathrm{a}+\mathrm{b}-}$ subjects (these are non-secretors). This agrees with our earlier observations on paraffin embedded sections of nonneoplastic urothelium. ${ }^{10}$

\section{Patterns of antigen staining in tumour tissues}

One aspect of the antigen staining patterns in the urothelial tumours - namely, the distribution of antigen positive tumour cells - is worthy of comment. In antigen positive tumours fluorescence was either randomly distributed among the tumour cells, or it was accentuated, or occurred exclusively in cells in the vicinity of blood vessels and connective tissues (basal pattern). As noted by Hammou et al ${ }^{28}$ a reverse pattern-that is, stronger fluorescence at a distance from the connective tissue stroma was not observed. Basal accentuation has also been noted in paraffin embedded sections of the normal urothelium. ${ }^{27}$ The lower incidence of this basal pattern of fluorescence in tumours of pT1 and higher stage, and in those that are poorly differentiated, is consistent with a loss of epithelial polarity and organisation in these tumours.

\section{Concluding remarks}

Clearly a lack of blood group antigen expression in bladder tumours is far from being the unambiguous marker of tumour invasiveness required for routine clinical use. In particular, the finding that $40 \%$ of the invasive tumours retained substantial amounts of antigen would seem to rule out the possibility of identifying all potentially aggressive tumours by blood group antigen loss. The possibility that antigen positive and antigen negative tumours are different disease entities, however, has not yet been ruled out. Follow up studies will be required to determine whether the antigen negative superficial tumours in this study are those that are destined to invade and whether there are differences in the behaviour of tumours with the various patterns of antigen distribution. Moreover, it is now quite clear that many hybridoma derived antibodies to onco-developmental antigens recognise blood group related carbohydrate structures, ${ }^{26-31}$ and there is much current interest in the possible participation of this family of carbohydrate structures in organisation and growth regulation in normal cells and the loss of growth control in tumour cells. Thus there are now ample opportunities to apply a large array of monoclonal antibodies to carbohydrate antigens to the study of bladder tumours and to widen the net in the search for "bad prognosis markers".

SJT is supported by the Cancer Research Campaign. We are grateful to the clinicians in the department of urology, Freeman Hospital, Newcastle upon Tyne for their help in providing the tissues used in these studies; and to the clinical and technical staff in the department of histopathology, Freeman Hospital, for their help in providing essential materials and storage facilities.

\section{References}

1 Prout GR. Heterogeneity of superficial bladder cancer. In: Bonney WW. Prout GR, eds. Bladder cancer. AUA monographs Vol 1. Baltimore: Williams and Wilkins, 1982:149-55.

2 Zinman LN. Bladder cancer-natural history. In: Garnick MB, Richie JP, eds. Urologic cancer. New York: Plenum Press, 1983:93-100.

3 Feizi T. Carbohydrate antigens in human cancer. Cancer surveys 1985;4:245-69.

4 Catalona WJ. Practical utility of specific red cell adherence test in bladder cancer. Urology 1981;18:113-7.

5 Limas C, Lange P. Altered reactivity for A, B, H antigens in transitional cell carcinomas of the urinary bladder. A study of the mechanisms involved. Cancer 1980;46:1366-73.

6 Stein BS, Kendall AR. Blood group antigens and bladder carcinoma: a perspective. Urology 1982;20:229-33.

7 Kay HEM, Wallace DM. A and B antigens of tumors arising from urinary epithelium. JNCI 1961;26:1349-65.

8 Fujita J, Matsumoto K, Kishi K, Ishiyama I. Synthesis of ABH blood group substances in bladder tumours. $\mathrm{Br} J$ Urol 1981;53:448-52.

9 Giraldo AA, Ruby SG, Humes JJ. Blood group antigens in urothelium in transitional cell carcinoma. Ann Clin Lab Sci 1983;13:307-14.

10 Thorpe SJ, Abel P, Slavin G, Feizi T. Blood group antigens in the normal and neoplastic bladder epithelium. J Clin Pathol 1983;36:873-82.

11 Szulman AE. Chemistry, distribution, and function of blood group substances. Ann Rev Med 1966;17:307-22.

12 Limas C, Lange P. A, B, H antigen detectability in normal and neoplastic urothelium. Influence of methodologic factors. Cancer 1982;49:2476-84. 
13 Classification of malignant tumours. 3rd ed. Union Internationale contre le Cancer. Geneva, 1978.

14 Mostofi FK. In: Histological typing of urinary bladder tumours. International Histological Classification of Tumours No 10. Geneva: World Health Organization, 1973.

15 Picard J, Waldron Edward D, Feizi T. Changes in the expression of the blood group A, B, H, Le and $\mathrm{Le}^{\mathrm{b}}$ antigens and the blood group precursor associated $\mathrm{I}(\mathrm{Ma})$ antigen in glycoprotein-rich extracts of gastric carcinomas. $J$ Clin Lab Immunol 1978;1:119-28.

16 Kapadia A. Feizi T, Jewell D, Keeling J, Slavin G. Immunocytochemical studies of blood group A, H, I and I antigens in gastric mucosae of infants with normal gastric histology and of patients with gastric carcinoma and chronic benign peptic ulceration. J Clin Pathol 1981:34:320-37.

17 Johnson GD, Davidson RS, McNamee KC, Russell G, Goodwin D, Holborow EJ. Fading of immunofluorescence during microscopy: a study of the phenomenon and its remedy. J Immunol Methods 1982:55:231-42

18 Coon JS, Weinstein RS. Variability in the expression of the $\mathrm{O}(\mathrm{H})$ antigen in human transitional epithelium. $J$ Urol 1981;125:301-6.

19 Vafier JA, Javadpour N, Worsham GF, O'Connell KJ. Double blind comparison of $\mathrm{T}$-antigen and $\mathrm{ABO}(\mathrm{H})$ cell surface antigens in bladder cancer. Urology 1984;23:348-51.

20 Javadpour N, Vafier J, Worsham GF, O'Connell K. Peroxidase antiperoxidase versus specific red cell adherence in detection of $\mathrm{O}(\mathrm{H})$ antigen in bladder cancer: a blind study. $J$ Surg Oncol 1984;27:112-5.

21 Coon JS, Weinstein RS. Detection of ABH tissue isoantigens by immunoperoxidase methods in normal and neoplastic urothelium. Comparison with the erythrocyte adherence method. Am J Clin Pathol 1981;76:163-71.

22 Sadoughi N, Misna J, Guinan P, Rubenstone A. Prognostic value of cell surface antigens using immunoperoxidase methods in bladder carcinoma. Urology 1982;20:143-6.
23 Flanigan RC, King CT, Clark TD, et al. Immunohistochemical demonstration of blood group antigens in neoplastic and normal human urothelium: a comparison with standard red cell adherence. J Urol 1983;130:499-503.

24 Srinivas V, Orihuela E, Lloyd KO, Old LJ, Whitmore WF. Estimation of $\mathrm{ABO}(\mathrm{H})$ isoantigen expression in bladder tumors. J Urol 1985;133:25-8.

25 Watkins WM. Biochemistry and genetics of the ABO, Lewis and $\mathrm{P}$ blood group systems. In: Harris $\mathrm{H}$, Hirschhorn $\mathrm{K}$, eds. Advances in human genetics. Vol 10. New York: Plenum Publishing, 1980:1-136, 379-85.

26 Feizi T, Gool HC, Childs RA, et al. Tumour-associated and differentiation antigens on the carbohydrate moleties of mucintype glycoproteins. Biochem Soc Trans 1984;12:591-6.

27 Juhl BR. Semiquantitative immunohistochemical evaluation of $\mathrm{H}$-antigen expression in human ureters of different $\mathrm{ABO}$ - and Lewis types. $J$ Histochem Cytochem 1985;33:867-74.

28 Hammou J-C, Fella C, Vacant J, Malolini R, Masseyeff R Improvement of the demonstration of $\mathrm{A}, \mathrm{B}, \mathrm{H}$ surface antigens in bladder tumors by a simple immunofluorescence technique. J Urol 1982:128:1183-7.

29 Hakomori S-I. Tumor-associated carbohydrate antigens. Annual Reviews of Immunology 1984;2:103-26.

30 Feizi $T$. Demonstration by monoclonal antibodies that carbohydrate structures of glycoproteins are onco-developmental antigens. Nature 1985;314:53-7.

31 Feizi T, Childs RA. Carbohydrate structures of glycoproteins and glycolipids as differentiation antigens, tumour-associated antigens and components of receptor systems. Trends in Biochem ical Sciences 1985;10:24-9.

Requests for reprints to: Dr Ten Feizi, Applied Immunochemistry Research Group, Clinical Research Centre, Watford Road, Harrow, Middlesex HA1 3UJ, England. 